\title{
ZPRÁVY
}

\section{Sociologie industriálních vztahů stále, resp. znovu aktuální?}

Naším cîlem je informovat o novém studijním programu na katedře sociologie FF UK a v této souvislosti rozvinout diskusi na téma aktuálnosti problematiky industriálních vztahů v podmínkách transformace české společnosti i v mezinárodním měrítku.

V letním semestru 1994 rozšî́ila katedra sociologie FF UK svůj studijní program o novou volitelnou jednosemestrální aplikaci zaměřenou na problematiku „Industrial Relations“. Tento zvláśtě v západní Evropě již pevně zakotvený interdisciplinární obor se zabývá problematikou institucionalizace industriálních vztahů na úrovni státu i organizací, trhu práce, kolektivního vyjednávání, participace pracujících, pracovních konfliktů. Jeho nezbytnou součástí je studium způsobu, jímž jednotliví aktéři - zaměstnanci, zaměstnavatelé a vláda - v rámci vzájemných vztahů vyvíjejí vlastní normy a pravidla pro regulaci pracovní sféry.

Cílem výuky „Industrial Relations“" na naší katedře je poskytnout studentům úvodní přehled problematiky, která v mnoha směrech překračuje hranice sociologie a která zároveň vykazuje značné perspektivy v oblasti aplikační. Zavedením této nové specializace se současně rozšiřuje spektrum uplatnění našich absolventů, protože v této oblasti Česká republika opravdu postrádá kvalifikované odborníky $\mathrm{z}$ důvodů jednostranného ustrnutí industriálních vztahủ během uplynulých čtyřiceti let. Vzhledem k evropské tradici si navíc lze jen těžko představit moderní kapitalistickou ekonomiku bez institucionalizovaných pracovních vztahů.

Zásadní podnět a především odborné a materiální zázemí pro zavedení této aplikační specializa- ce získala naše katedra účastí v projektu TEMPUS, zaměřeném na rozvoj výuky industriálních vztahů $\mathrm{v}$ některých zemích bývalého východního bloku. Kromě pomoci ze strany západoevropských partnerů z Univerzit Bielefeld, Nijmegen a Warwick při sestavování výukového programu, vyškolení učitelů v rámci týdenních seminár̆ů na výše zmíněných univerzitách bylo hlavním cílem této spolupráce $\mathrm{v}$ rámci projektu TEMPUS vydat mezinárodní učebnici (podzim 1994).

Tato učebnice má kromě obecného úvodu do problematiky industriálních vztahů (v západoevropských zemích hovoříme spiśe o pracovních, příp. zaměstnaneckých vztazích vzhledem $\mathrm{k}$ poklesu významu průmyslu) poskytnout přehled o současném stavu této problematiky v Bulharsku, České republice, Mad'arsku, Nizozemí, Polsku, SRN a Velké Británii. Také v šesti kapitolách věnovaných jednotlivým tematickým okruhům se uplatňuje především srovnávací hledisko v mezinárodní i historické perspektivě. Tento přístup si vyžádal obzvlášt' od autorů z postkomunistických zemí studium současné situace v oblasti, ve které došlo $\mathrm{k}$ radikálním změnám a která alespoň u nás není dosud systematičtěji zkoumána (v Polsku a Madarsku jsou na tom $v$ tomto ohledu mnohem lépe).

Čistě pedagogické zaměření projektů TEMPUS bylo tak $\mathrm{z}$ důvodů získání a zpracování aktuálních informací nutné rozšriritit o výzkumnou složku. $\mathrm{V}$ př́padě našeho pracoviště jsme $\mathrm{k}$ tomuto účelu částečně využili granty Akademie věd ČR a Univerzity Karlovy, které jsou tematicky orientované na industriální vztahy v průběhu transformace čes- 
kých podniků (odpovědný řešitel dr. J. Buriánek). Nelze opomenout spolupráci $s d r$. Kuchařem z ISPV FSV UK, dr. Hradeckou a dr. Vláčilem z Ústavu sociologie AV ČR, kteří se v současnosti také věnují zkoumání industriálních vztahů.

$\mathrm{V}$ budoucnosti počítáme s otevřením postgraduálního kurzu, určeného především pracovníkům z oblasti odborů, úradů práce, zaměstnavatelských a podnikatelských svazů, státní správy, kterým bychom také chtěli zprostředkovat potřebné znalosti $\mathrm{z}$ této oblasti. Navíc pro nás bude kontakt $\mathrm{s}$ účastnîky kurzu velmi užitečnou zpětnou vazbou akademického pohledu s českou realitou industriálních vztahů.

Mezinárodní zkušenosti s tímto tématem bychom měli nadále čerpat ze spolupráce $\mathrm{v}$ rámci projektu TEMPUS, zaměřeného na vliv privatizace na industriální vztahy a v rámci akcí a kontaktů zprostředkovaných např. „European Foundation for the Improvement of Living and Working Conditions" se sídlem Dublinu. Další možnosti kontaktů vyplývají ze skutečnosti, že evropské industriální vztahy získaly v letošním roce publikační zázemí $\mathrm{v}$ podobě vlastního časopisu stejného názvu, což nejen zdůrazňuje jejich aktuálnost, ale především význam evropské tradice Industrial Relations (budované m.j. k zajiššění sociálního smíru). Jak již naznačily přednášky špičkových evropských odborníků R.Hymana z University of Warwick a E.Diettricha $z$ Universität Bielefeld které měly v rámci výuky napomoci uvedení pro- blematiky industriálních vztahů do našich podmínek, dochází i v západních zemích $\mathrm{k}$ velkým změnám, které si žádají i reakci odborníků. Právě srovnání dvou zcela odlišných systémů industriálních vztahů, které existují v SRN (právně zakotvený dualistický systém podnikových rad a odborových organizacî) a Velké Británii (volné kolektivní vyjednávání mezi odbory a zaměstnavateli), ukázalo nezbytnost porozumění národních systémů a kulturních specifik pro vysvětlení podstaty jejich rozdílného fungování. Úkolem sociologie, která obhájila oprávněnost svého př́stupu $\mathrm{k}$ problematice industriálních vztahů před ekonomy již v 50. letech (Industrial Relations jsou v tomto případě považovány za oblast studia a analýzy a ne za samostatnou vědní disciplínu), se ve spolupráci s historiky, právníky, ekonomy, sociálními psychology a politology v našich podmínkách jeví především:

- ustálení pojmového aparátu a rozvoj výuky $\mathrm{v}$ této oblasti;

- výzkum v oblastech ekonomických procesů a trhu práce, tripartity a jejího fungování $v$ našem politickém systému, pracovního práva (Zákoník práce, Zákon o kolektivním vyjednávání, stávky), kolektivního vyjednávání ve smyslu strategie chování aktérů, participace pracujících, neúspěchu myšlenky zavedení podnikových rad, nové role odborů atd.

Ivana Mazálková 